\title{
Social, biological, and environmental drivers of the hunting and trade of the endangered yellow-footed tortoise in the Amazon
}

\author{
Thaís $Q$. Morcatty $^{1}$ and $\underline{J o a ̃ o}$ Valsecchi $^{1}$
}

\begin{abstract}
Chelonians constitute an important source of food and income for the inhabitants of tropical forests. We assessed the social, biological, and environmental factors affecting the hunting and trade of the endangered yellow-footed tortoise (Chelonoidis denticulata) in rural and urban areas in the Amazon and estimated the sustainability of tortoise use. We also discuss possible conservation alternatives that are compatible with the needs of local inhabitants. We monitored tortoise hunting and trade for 12 years in 10 traditional communities that exploit different habitat types in the Brazilian Amazon and collected data on the tortoise trade in two urban markets for six years. In upland forests, tortoise hunting mainly occurred during the dry season; in whitewater flooded forests, hunting mainly occurred during the flood season. The tortoise trade was carried out nearly entirely by whitewater flooded forest users and was intimately related to fishing, the main economic activity in these communities. Furthermore, the tortoise trade was encouraged in whitewater flooded forests because this environment yielded significantly heavier tortoises than upland forests, and we observed a strong relationship between trade probability and tortoise size. The tortoise trade was found to primarily supply nearby urban centers, generating high monetary gain. Female tortoises suffered greater hunting pressure and were more valued in the bushmeat market. The productivity of tortoise hunting in the monitored communities severely decreased with time. In addition, the price per kilogram of tortoise greatly increased in the urban market. Given this unsustainable scenario, policies regulating tortoise hunting in the Amazon are needed. These policies must be adapted to the different patterns of tortoise use by rural communities while maintaining the culture and food sovereignty of the local inhabitants.
\end{abstract}

Key Words: bushmeat market; chelonians; hunting sustainability; rural communities

\section{INTRODUCTION}

Balancing hunting activity with the conservation of biodiversity remains a major challenge. Game meat is one of the most important sources of consumed protein, fat, and micronutrients in rural communities, where access to commerce is limited and raising domestic animals is difficult (Ayres et al. 1991, Redford 1997). Hunting in remote rural areas is often essential for the survival of local residents because it ensures food security for the population, contributes to the maintenance of social and cultural ties, and contributes to healthy diets, which often cannot be maintained by domestically produced food (Ibarra et al. 2011). Simultaneously, because of various examples of unsustainable hunting around the world, hunting is considered by many authors to be a major anthropogenic driver of biodiversity loss (Bennett et al. 2007).

The harvest rate of wildlife is particularly high in tropical regions. Fa and Peres (2001) report the consumption of between 1 and 3.4 million tons of game meat annually by rural people in Central Africa, and Nasi et al. (2011) estimated that at least 6 million tons of bushmeat are consumed annually in the Congo and Amazon basins. A substantial fraction of the bushmeat harvested in tropical regions also provides income to hunters and their families through the sale of this product to urban markets. Although urban residents have several options for protein sources, game meat consumption remains common because of the low cost of the product and an appreciation for cultural traditions (Aiyeloja and Ajewole 2006, van Vliet and Mbazza 2011).

Many studies have reported the expansion of subsistence hunting and urban game meat markets in tropical regions and suggested solutions for avoiding the overexploitation of wildlife (van Vliet et al. 2012). However, most of these studies have focused on African tropical forests rather than on bushmeat consumption by rural and urban residents in the Amazon (Nasi et al. 2011). Some authors have suggested that bushmeat consumption in the Amazon is minimal because nearly all inhabitants have access to sources of protein from livestock breeding (Rushton et al. 2005, Nasi et al. 2011). Conversely, Peres (2000) estimated that approximately 23.5 million wild animals are consumed each year by locals in the Brazilian Amazon. This annual extraction rate would amount to a meat market of approximately US\$191 million, second only to logging among extractive activities in Brazil. Bodmer and Lozano (2001) estimated a value of US\$1,131,910 in annual game meat consumption in the Peruvian Amazon, with urban consumers spending at least US\$250,268 annually in the Iquitos bushmeat market.

Despite providing valuable information regarding harvesting rates, several studies estimating the magnitude of hunting and assessing its sustainability in the Amazon were restricted to a short sampling time and performed on a sporadic basis. In addition, current information regarding game meat consumption in rural and urban areas in the Amazon is concentrated near easily accessible cities, whereas remote communities and isolated cities have rarely been included in relevant studies (e.g., De SouzaMazurek et al. 2000, Hurtado-Gonzales and Bodmer 2004). All of these factors hinder our understanding of the large-scale effects of hunting and trading target species in the Amazon.

The Amazon forest, although classified as a single biome, consists of various types of environments (Colinvaux and Bush 1991), and the use of wildlife by human populations can differ widely among these environments (Valsecchi and Amaral 2009). Therefore,

${ }^{1}$ Research Group on Terrestrial Vertebrate Ecology, Mamirauá Sustainable Development Institute 
long-term studies that provide a greater understanding of the ecological, social, economic, and cultural dimensions related to hunting are required in this biome (Nasi et al. 2011).

For example, an animal's behavior and susceptibility to hunting may be influenced by environmental factors in the Amazon. Valsecchi et al. (2014) determined how river water levels, moon illumination, and different types of Amazonian ecosystems affect lowland paca (Cuniculus paca) hunting in the Central Amazon. In addition, preferences for certain biological characteristics, such as animal size or sex, can result in selective killing (e.g., Nielsen and Meilby 2015). The wealth of local families and their dependence on hunting for income are also important economic factors that may determine the intensity of bushmeat consumption and trade in rural and urban areas (e.g., Fa et al. 2009). Similarly, cultural factors, such as the hunting methods used, medicinal properties of wild animals, and taboos, can influence hunting patterns and bushmeat consumption by Amazonian residents (van Vliet and Nasi 2008). Together, all of these drivers of hunting will impact the effectiveness of policies for regulating hunting in the Amazon. In addition, the main target game species are not equally included in studies on hunting in the Amazon. Knowledge of the unique aspects of the hunting of each primary game species can contribute to our understanding of a wide range of hunting practices in this biome.

Although not included in most hunting studies, chelonians are among the main hunted species in the Amazon (Fachin-Terán et al. 2004). In addition to being hunted for subsistence, freshwater turtles and tortoises are hunted for sale. These animals can achieve high market values because their taste is appreciated by consumers, because of cultural elements such as the consumption of freshwater turtles and tortoises during holiday celebrations, and because it is easy to keep them alive until they are sold (Ross et al. 1978, Valsecchi and Amaral 2009). The high consumption and trade rates of chelonians have caused them to become one of the most threatened vertebrate groups in the world (Turtle Conservation Coalition 2011). Peres (2000) noted that tortoises (Chelonoidis spp.) have the highest rates of per capita consumption and represent the largest amount of biomass harvested among chelonians in the Brazilian Amazon. Bisbal (1994) and Aquino et al. (2007) also demonstrated that tortoises are largely represented as a target species among all species hunted in rural areas in Venezuela and Peru.

The yellow-footed tortoise (Chelonoidis denticulata) is the most widely distributed tortoise species in the Amazon. The overexploitation of this species for consumption, trade, and the pet industry has mainly resulted in its classification as vulnerable to extinction by the International Union for Conservation of Nature (IUCN; Páez et al. 2012) and its inclusion in Appendix II of the Convention on International Trade in Endangered Species of Wild Fauna and Flora (IUCN 2013). In contrast, chelonian monitoring and conservation projects generally do not consider the yellow-footed tortoise in their conservation efforts. Therefore, understanding the roles of yellow-footed tortoise hunting for the subsistence and income of rural people in the Amazon is an important step for developing conservation strategies for this endangered species and for maintaining food sovereignty for rural populations.
In this study, we analyzed data from our 12-year hunting monitoring project in the Central Amazon to (1) assess the social, biological, and environmental factors that influence the hunting and trade of yellow-footed tortoises in rural and urban areas; (2) estimate the sustainability of yellow-footed tortoise hunting and trade in the region; and (3) discuss possible alternatives for the conservation of the yellow-footed tortoise that are compatible with the needs of the inhabitants of the Amazon.

\section{METHODS}

\section{Study area}

We conducted the study in the middle region of the Amazon River in the Brazilian Amazon (Fig. 1). We monitored the hunting of yellow-footed tortoises by traditional communities inhabiting two Sustainable Development Reserves (Class IV, IUCN). The Mamirauá Sustainable Development Reserve $\left(03^{\circ} ; 08^{\prime} S\right.$; $\left.64^{\circ} ; 45^{\prime} \mathrm{W}\right)$ comprises $1124 \mathrm{~km}^{2}$ and mainly consists of forests flooded by whitewater rivers, which are referred to as whitewater flooded forests or várzeas. Whitewater flooded forests remain completely flooded during long periods of the year (FerreiraFerreira et al. 2015), which limits the occurrence of most terrestrial animals (de Queiroz 2011). The Mamirauá Sustainable Development Reserve has a population of approximately 11,000 inhabitants distributed in 145 communities.

Fig. 1. A map showing the two studied reserves, the communities monitored for tortoise hunting, and the main urban centers near the study area in the Brazilian Amazon. Bom Jesus do Baré and Boa Esperança are communities exclusively users of upland forests; São Francisco do Aiucá, Barroso, Boca do Mamirauá, Sítio Fortaleza São José, and São Raimundo do Jarauá are communities exclusively users of whitewater flooded forests; Nova Jerusalém do Amanã, Belo Monte, and São José do Urini are communities users of both environments.

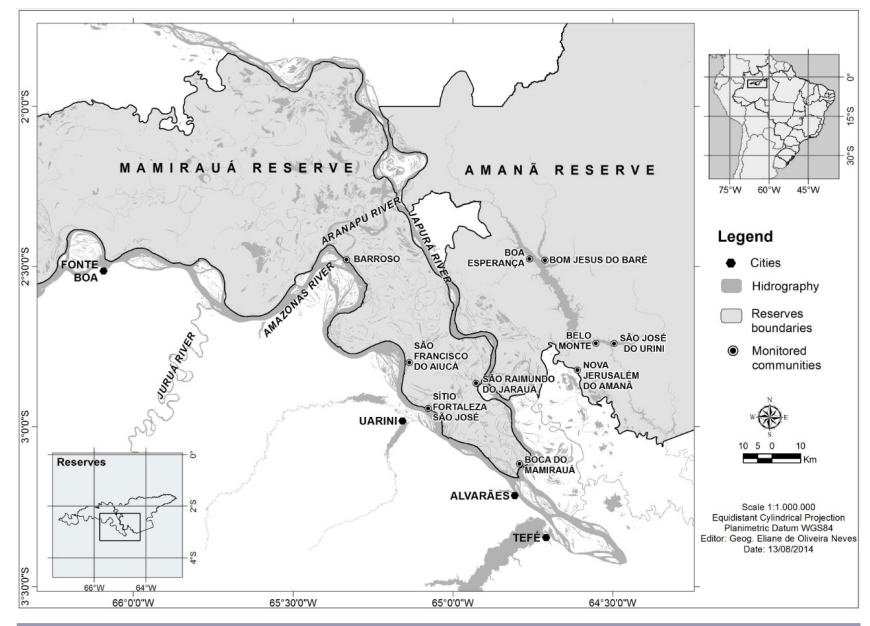

The Amanã Sustainable Development Reserve $\left(03^{\circ} ; 16^{\prime}\right.$ 'S $65^{\circ} ; 23^{\prime} \mathrm{W}$ ) comprises $2350 \mathrm{~km}^{2}$ and mainly consists of upland forest (terra firme), and whitewater flooded forests and blackwater flooded forests (igapó). This reserve is predominantly composed of upland forests, with blackwater flooded forests covering the smallest total area. The Amanã Sustainable Development Reserve 
has a population of approximately 4000 inhabitants that live in 57 communities.

We selected 10 communities to monitor tortoise hunting according to the main environments exploited by residents. Two of the monitored communities are exclusive users of upland forests, five communities are exclusive users of whitewater flooded forests, and three are users of both environments (Fig. 1). Agriculture is the main economic activity of community users in upland forests, whereas white-water flooded forest community members are mainly fishers because flooding hinders agriculture.

In addition, we collected information regarding the trade of yellow-footed tortoises in the urban markets of the municipalities of Alvarães and Tefé, two urban centers located near the reserves. The municipality of Alvarães has approximately 15,000 inhabitants, and Tefé has approximately 62,000 inhabitants.

\section{Data collection}

Between 2003 and 2013, we monitored yellow-footed tortoise hunting in 10 rural communities that were classified into 3 types of exploitation patterns in Amazonian environments. We hired a local resident in each community to record daily information regarding hunting events, which were voluntarily reported by other community members. The local collector recorded the following information: the time spent by hunters in tortoise hunting, the activity performed during tortoise hunting (whether it was an intentional or opportunistic encounter with the animal), the number of hunters involved in the hunting events, the period of the day, the hunting location, the tools used to capture the tortoise, the number of individuals hunted, biometric data, the sex of the hunted specimens, the destinations of the animals (whether they were consumed or sold), and their selling price if sold.

We considered data on the frequency of intentional expeditions to hunt yellow-footed tortoises, the motivation for hunting (consumption or trade), the methods used for hunting, the number of people involved in hunting, and the period of the day during which hunting was performed as social and cultural factors that influenced the hunting and trade of yellow-footed tortoises. We considered the sex, length, and weight of the hunted animals as biological factors that influenced tortoise hunting and trade. Finally, we considered differences in tortoise hunting patterns in upland forests and whitewater flooded forests as environmental factors that influenced tortoise hunting and trade.

Furthermore, we conducted interviews in urban centers in the cities of Alvarães and Tefé in 2007 and between 2009 and 2014, respectively. However, continuous daily collections were only conducted during the last two years in Tefé. We interviewed hunters in the city and intermediaries of game meat bound for urban markets to determine the amounts and prices of tortoises sold. We considered the people who claimed to have captured the animals in the forest as hunters and those who bought the tortoises from hunters and intended to sell them to local traders as intermediaries. We were unable to conduct interviews with traders in the city.

\section{Data analysis}

We analyzed the social and cultural factors influencing yellowfooted tortoise hunting and trade by using descriptive analyses and calculating the frequency of intentional hunting expeditions, the average number of hunters involved in each event, the most common method used, the preferred period of the day, the destinations of the tortoises, and their sale prices. We analyzed the influences of biological factors on hunting by comparing the proportions of males and females hunted in different habitats using the chi-square test. The length of the carapace between the sexes was compared using a Student $t$ test, and the body weights between the sexes and environments were compared using a twoway analysis of variance.

For biological factors influencing trade, we estimated the probability of males and females to be sold according to their body weight using logistic regression. In addition, we tested the relationship between body weight and tortoises selling price by rural hunters using linear correlation. We analyzed the effects of environmental factors on tortoise hunting and trade by using descriptive analyses to determine the harvesting seasons by environment and by comparing the consumption and trade ratios for each type of environment used by the communities by applying the chi-square test.

We used two indexes to assess the sustainability of tortoise hunting and trade in the study area. We calculated the catch-perunit-effort (CPUE) index using the biomass per hunter per hour of effort applied during yellow-footed tortoise hunting events $(\mathrm{kg} /$ man*hour) as a measure of harvest productivity. For this analysis, we only included intentional tortoise-hunting events. In addition, we evaluated trends in yellow-footed tortoise sale prices sold over the monitored years using linear correlation.

We adjusted the selling prices according to inflation, with reference to the General Price Index for Brazil estimated by the Getúlio Vargas Foundation. We used the exchange rate on November 4, 2014, to convert the Brazilian real into US dollars $(\mathrm{R} \$ 2.50=\mathrm{US} \$ 1.00)$. Statistica 8.0 software (http://www.statsoft. com/) was used for all statistical analyses, and we considered results significant at $\mathrm{p}<0.05$.

\section{RESULTS}

\section{Factors influencing tortoise hunting by rural communities}

\section{Social aspects of hunting}

We recorded 604 hunted Chelonoidis denticulata individuals that were obtained across 327 hunting events, with a total biomass of $5533.1 \mathrm{~kg}$. Most tortoise hunting trips were carried out during the day $(97.4 \%)$ by a lone hunter or a pair of hunters $(64 \%)$. Many of the captured tortoises were products of hunting events performed over the course of several hours, which lasted between 8 and 12 hours $(50.18 \%)$. Each hunting event obtained an average of $1.82( \pm 1.6)$ tortoises, although records indicated some hunting events resulted in the capture of up to 15 individuals. The most frequently used method for hunting tortoises was to visually search the locations used by the animals for shelter, feeding, or thermoregulation $(74.17 \%, \mathrm{n}=448)$. Hunting dogs, which are widely used in the Amazon, were used on a smaller scale for yellow-footed tortoise hunting in this region $(12.6 \%, \mathrm{n}=37)$.

Most tortoise captures were linked to opportunistic encounters with the animal $(59.1 \%, \mathrm{n}=357)$ when performing other activities, such as hunting other species, fishing, farming, or gathering Brazil nuts. However, the number of intentional tortoise-hunting events was high $(41.9 \%, \mathrm{n}=253)$, indicating that hunters highly prize this species. 
Biological and environmental aspects of hunting

Hunting of female tortoises occurred more frequently than the hunting of male tortoises $(57.4 \%, \mathrm{n}=313$ females; $42.6 \%, \mathrm{n}=$ 232 males; $\chi^{2}=1.22$, df $\left.=1, p<0.05\right)$ in both upland and whitewater flooded forests $\left(\chi^{2}=3.51, \mathrm{df}=2, \mathrm{p}>0.05\right)$. Females and males presented similar straight carapace lengths, which were $402.8 \pm 35 \mathrm{~mm}$ for females and $405.1 \pm 51 \mathrm{~mm}$ for males $(\mathrm{t}=0.67$, $\mathrm{df}=484, \mathrm{p}>0.05)$. The same relationship was observed for the weight of the hunted individuals $\left(\mathrm{F}_{1,310}=2.51, \mathrm{p}>0.05\right)$. However, the whitewater flooded forests yielded significantly heavier tortoises than the upland forests $\left(F_{1,310}=93.84, p<0.01\right.$; Fig. 2$)$.

Fig. 2. Influence of the sex and the environment on the weight of yellow-footed tortoises (Chelonoidis denticulata) hunted in the Brazilian Amazon. The bars represent 95\% confidence intervals.

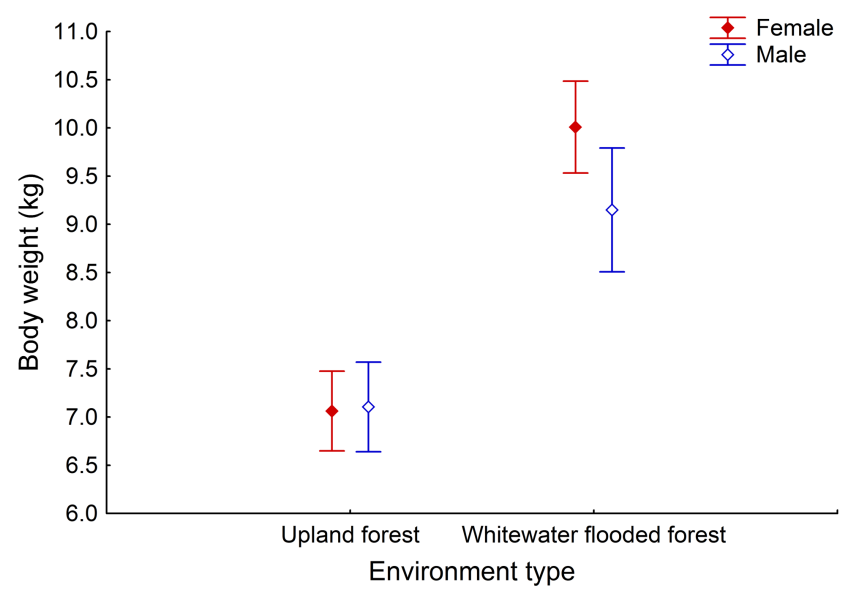

Yellow-footed tortoise hunting increased during two seasons of the year; however, these periods varied according to the environment. In upland forests, tortoise hunting mainly occurred during the dry season between November and January. In whitewater flooded forests, hunting mainly occurred during the flood season between May and July (Fig. 3).

\section{Factors influencing the tortoise trade in rural and urban areas}

\section{Social and cultural aspects of the trade}

The tortoise trade was almost entirely practiced by residents of whitewater flooded forests. Tortoises hunted in upland forest communities were primarily consumed, whereas more tortoises hunted in whitewater flooded forest communities were sold than consumed $\left(\chi^{2}=152.03\right.$, df $=3, p<0.01$; Fig. 4). Even among community users of both environments, hunters tended to sell proportionately more tortoises from whitewater flooded forests than from upland forests.

Most of the hunted tortoises with a declared destination were sold $(58.7 \%, \mathrm{n}=334)$, with urban markets being the most frequent destinations $(70 \%, \mathrm{n}=119)$. The municipalities of Tefé and Uarini were the main recipients of tortoises sold by hunters. In addition to selling tortoises in urban centers, hunters sold tortoises to people within their own communities or neighboring communities (31.4\%). According to local traditions, the yellowfooted tortoises were always traded alive by the hunters, even when many months had lapsed between the hunting event and the sale to the consumer.
Fig. 3. Mean of captures of tortoises per month over the 12 years of hunting monitoring in upland forests and in whitewater flooded forests in the Brazilian Amazon. Bars represent standard errors.

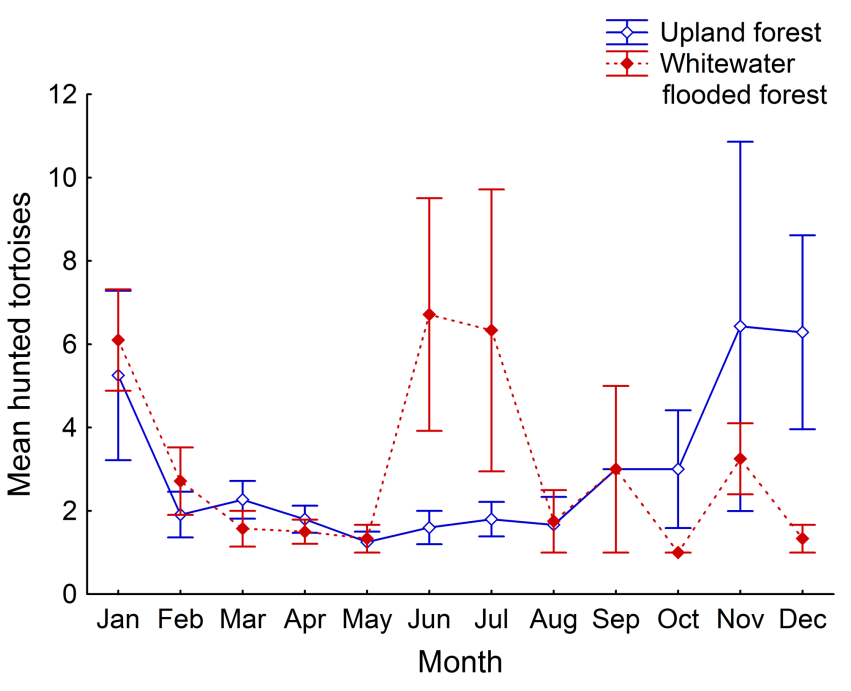

Fig. 4. Patterns of consumption and trade of yellow-footed tortoises (Chelonoidis denticulata) by community type according to the environment exploited.

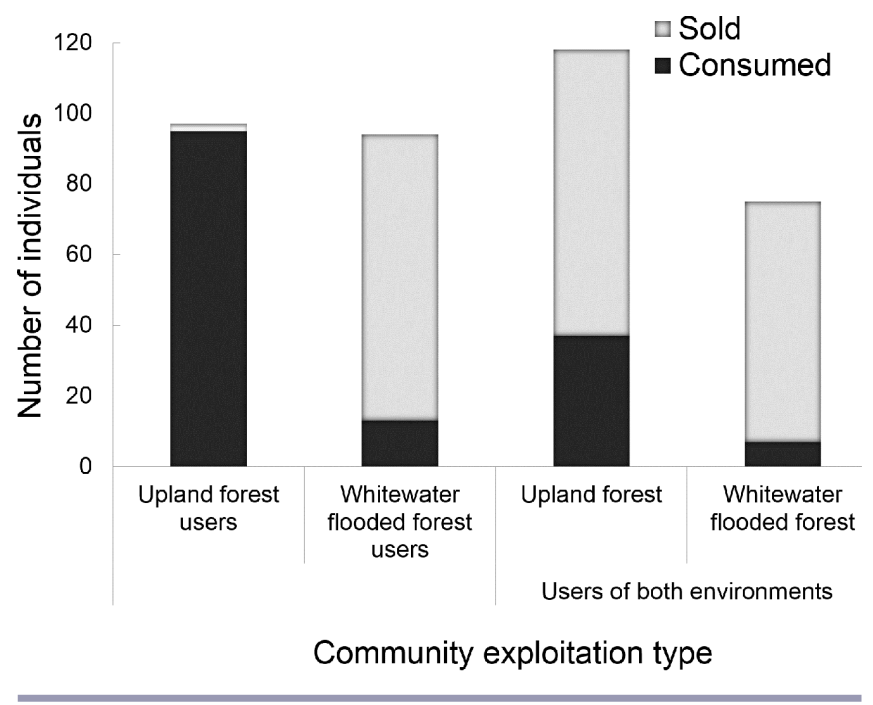

Biological and environmental aspects of the trade

The hunters' decisions to sell female tortoises to urban centers were influenced by the individual's body weight because females with higher body weights were more often sold to urban centers than locally consumed $\left(\chi^{2}=23.30\right.$, df $=1, p<0.01$; Fig. 5). In contrast, weight did not influence the selling probability of male tortoises $\left(\chi^{2}=0.13\right.$, df $\left.=1, p>0.05\right)$. To price the yellow-footed tortoises, the hunters account for the sex and body weight of the individual. The average price per kilogram is very similar between females (US\$1.04 \pm US\$0.36) and males (US\$1.00 \pm US\$0.36; t 
$=0.80, \mathrm{df}=180, \mathrm{p}>0.05)$. However, the price of females was strongly determined by body weight, with larger females being sold at a higher price in both urban centers $\left(\mathrm{r}=0.49, \mathrm{p}<0.05, \mathrm{r}^{2}\right.$ $=0.24, \mathrm{n}=58)$ and within the reserves $\left(\mathrm{r}=0.68, \mathrm{p}<0.05, \mathrm{r}^{2}=\right.$ $0.47, \mathrm{n}=23$ ). Conversely, weight did not influence the price determined by hunters for males, regardless of the selling destination $\left(\mathrm{r}=0.26, \mathrm{p}>0.05, \mathrm{r}^{2}=0.07, \mathrm{n}=33\right.$, for urban centers; $\mathrm{r}=0.32, \mathrm{p}>0.05, \mathrm{r}^{2}=0.1, \mathrm{n}=24$, for hunters' and neighboring communities).

Fig. 5. Trade probability of female tortoises to urban centers as a function of body weight.

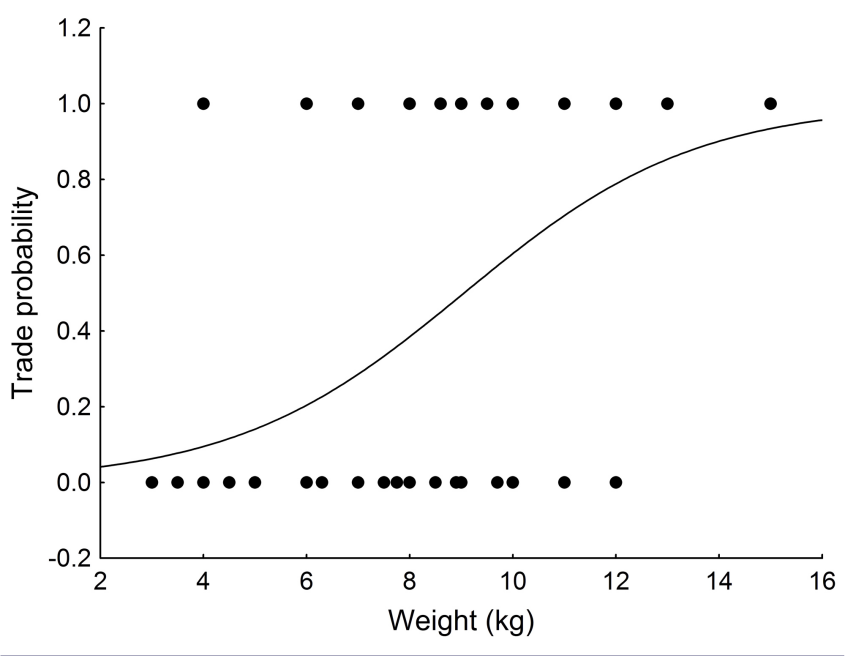

The pricing of yellow-footed tortoises

The prices of tortoises sold by hunters from the reserves varied according to the destination of the sale. During the last two years, the hunters decided that they would charge an average of US\$10.76 ( \pm US\$3.0) per individual in trades within their own community or neighboring communities, which is equivalent to US\$1.30/kg ( \pm US\$0.4). Simultaneously, hunters significantly increased the amount they charged per tortoise when selling to intermediaries bound for urban markets, charging US\$14.75 ( \pm US\$4.6) to intermediaries bound for Uarini and US\$15.88 ( \pm US\$4.3) for those bound for Tefé, which is equivalent to US\$1.86/ $\mathrm{kg}$ ( \pm US\$0.6).

We obtained records of 64 yellow-footed tortoises that were sold directly in urban centers. In the city of Alvarães, tortoise prices ranged from US\$2.00 to US\$20.00. In Tefé, hunters from various localities sold tortoises to intermediaries for US\$29.76 ( \pm US\$4.2) each. The intermediaries resold the tortoises to traders for approximately US\$45.44 ( \pm US\$9.8), generating a profit of between US\$8.00 and US\$16.00 per individual. Thus, from the first sale of tortoises transacted by hunters in the city to their availability to the end consumers, the prices of the traded individuals increased by at least $153 \%$.

\section{Sustainability of yellow-footed tortoise harvest}

The productivity of intentional tortoise hunting in the monitored rural communities has decreased over the years $(r=0.82, p<0.05$, $\mathrm{r}^{2}=0.67$; Fig. 6A). An outlier value of CPUE was found in 2009; thus, we excluded this year from the analysis. Our data indicated that tortoise hunting in this region may become very difficult and unproductive in six years. Additionally, the prices per kilogram of tortoises sold by hunters from the studied reserves and in cities have increased over the years $\left(r=0.66, p<0.01, r^{2}=0.44\right.$; Fig. $\left.6 B\right)$.

Fig. 6. (A) Negative trend of tortoise hunting productivity (catch per unit effort) over the years of monitoring, considering both upland and whitewater flooded forests. (B) Increasing trend of the price per kilogram of tortoises sold by hunters of the studied reserves to the urban market.

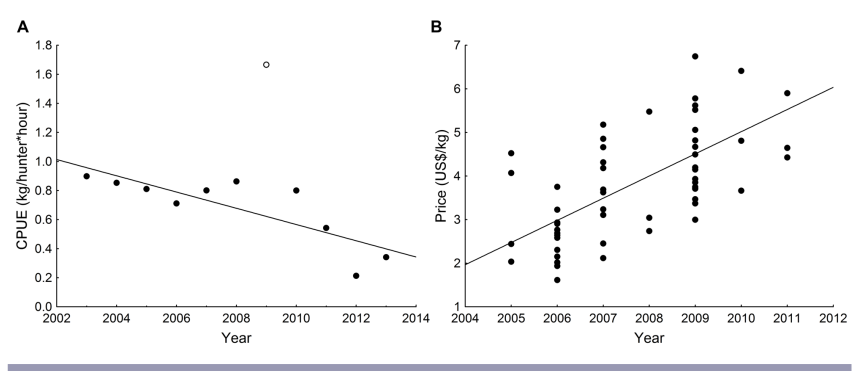

\section{DISCUSSION}

Social, biological, and environmental drivers that determine the hunting intensity of yellow-footed tortoises may also indicate ways to promote conservation strategies for this species. For most hunting events, social factors, such as the number of hunters and the period of the day, were the factors affecting the hunting of most species in the region (Valsecchi and Amaral 2009). However, unlike other regions of the Amazon, we detected a low frequency of the use of dogs to capture tortoises (Koster 2008). Dogs are normally interested in detecting and chasing animals that move or emit sounds. To find tortoises, dogs must be capable of detecting animals that remain hidden, motionless, and silent when subjected to a threatening situation. Therefore, possible obstacles to applying this method are the need for intensive dog training to locate tortoises in the forest and the high occurrence of hunting in flooded forests, where the exclusive use of canoes during the flood season limits dog activities. In contrast, successful capture through a visual search is conditional on the hunter's ability to detect the tortoise and promotes the development of experts in the capture of this animal. This specialist training is corroborated by the high number of intentional hunting events detected, especially in communities where the trade of the species is frequent.

The high number of female tortoises hunted in the reserves is an important biological indicator of the segment of the population that is most severely affected by hunting. Because males and females have similar biometric measurements, the larger number of females hunted may not be influenced by the size of the animals. Therefore, the greater numbers of females among the hunted individuals may result from a higher proportion of females in the wild or from sex-biased harvesting by hunters. In contrast with our results, Jerozolimski(2005) estimated that a higher proportion of males than females were present in wild populations of Chelonoidis denticulata in the Brazilian Amazon (1.28:1). Throughout the Amazon biome, female chelonians are more appreciated for consumption because of their higher fat content and because they may have eggs inside their bodies. This finding 
supports the hypothesis of sex-biased harvesting of Chelonoidis denticulata during hunting. Because this preference for females is closely related to reproductive aspects of the species, this pattern of hunting may compromise population growth rates and should be considered in conservation strategies.

Environmental factors, such as climate, water levels, and vegetation, combine to promote seasons during which a predominance of yellow-footed tortoise hunting occurs. These seasons are opposite in upland and whitewater flooded forests. In upland forests, tortoises become concentrated within small lowland areas in the forests that remain moist during the dry season, which attracts hunters to these locations. In contrast, tortoises have fewer shelter options during the flooding period in whitewater flooded forests; thus, they become more detectable by hunters. We also recorded a high intensity of tortoise hunting in January in the whitewater flooded forests. Although January is a month of low water, this period coincides with the fructification of the Java plum tree (Spondias lutea), a common plant species in Amazonian whitewater floodplains that is consumed by the tortoises in this region. The numerous fallen fruits attract the tortoises, which facilitates their detection by hunters around these trees. The considerable traditional knowledge of the local residents concerning tortoise behavior allows for high tortoise hunting success in both environments.

Our results show the importance of considering these two main Amazonian environments as distinct when describing hunting activities, evaluating their impacts, and implementing conservation policies. The trade of tortoises is also strongly influenced by social and environmental factors, which greatly differed between upland and whitewater flooded forests. Although the motivation for hunting tortoises in upland communities is subsistence consumption, the motivation in whitewater flooded forest communities is primarily to obtain financial resources.

The incomes of communities in upland forests are linked to agricultural production, with periodic sales aligned with cultivation cycles. In addition, communities that are exclusive users of the upland forests monitored in the reserves are near blackwater rivers, which have lower amounts of fish. Thus, the inhabitants near blackwater rivers are more dependent on game meat for subsistence and disfavor bushmeat trade. In turn, the incomes of whitewater flooded forest communities or users from both environments are predominantly linked to fish. Contrary to the suggestions of many authors, the high abundance of fish in whitewater rivers is not sufficiently correlated with reduced hunting pressures (e.g., Nasi et al. 2011). Whitewater flooded forest residents, although less dependent on game for subsistence, still collect tortoises to obtain income during various periods of the year. Tortoises in whitewater flooded forests become more detectable during the flood season, which corresponds to the period when obtaining fish becomes more difficult. The absence of large mammals that are often hunted in upland forests (Peres 1999, de Queiroz 2011) and the increase in tortoise capture during a particular season demonstrate the importance of this species in the economics of whitewater flooded forest communities.

Additionally, the communities in whitewater flooded forests use the reliable fish market for trading captured tortoises. The wellestablished trade system of game products was also noted by
Nielsen and Meilby (2015) as an important driver of the sale of game meat in Africa. Another factor that contributes to the trade of tortoises from whitewater flooded forests is the high productivity of this environment, which results in heavier tortoises.

We observed that the decision to sell or consume hunted tortoises is motivated by individual weight because larger individuals provide greater monetary gain. This relationship is primarily positive for females, which indicates that buyers do not randomly prefer large individuals but rather select large females because of the greater probability that they will contain eggs. For the same reason, only the females have sale prices related to body weight. Males are randomly priced depending more on the decision of the hunter than on size.

We observed that the sale of tortoises by rural residents was mainly conducted to supply nearby urban centers. As noted by Fa et al. (2009) in Africa, even in urban sites where there is access to other legal meats such as chicken and beef, the consumption of game meat remains high. This practice endures because much of the urban population in tropical countries is still closely linked to rural culture, preferring game meat to domestic sources of protein (Nasi et al. 2011).

However, our sales records in the city are sparse because of the difficulties in obtaining information regarding urban markets. van Vliet et al. (2014) showed that the yellow-footed tortoise represents an important proportion of the bushmeat sold in Peru markets but not in Brazil. Our work indirectly indicated that the sale of tortoises in the Brazilian urban market should not be disregarded. Therefore, greater efforts should be made to understand this market.

For hunters, the sale of game meat to urban centers is more profitable than the sale in rural areas because meat commands a higher price in urban centers. We observed three categories of people involved in the sale of tortoises, and the price of the meat increased at every step in the marketing chain. In some cases, the intermediaries profited more than the hunters, and the traders likely profited even more.

In some regions, game meat is a cheap source of protein and is crucial for the poorest urban households. However, in other regions, bushmeat commands high prices that only the richest people can afford (Nasi et al. 2011, van Vliet et al. 2012). Tortoise meat in Tefé was more than twice as expensive as chicken (US\$2.00/kg), the main domestic animal consumed in the region, and approached the price of the cheapest beef options available in the city (US\$4.40/kg). In addition, tortoise meat costs 10 times more than the most popular fish species in Tefé. Thus, in this Amazon region, tortoise meat is not the cheapest source of available protein, and urban residents have chosen to pay a higher price to consume this game meat.

\section{Sustainability of the yellow-footed tortoise harvest}

The rapid growth of rural and urban populations and increased accessibility to remote areas of the forest promote overhunting of the game species (Albrechtsen et al. 2007), which was quickly perceived when analyzing the productivity of tortoise hunting in Central Amazonia. The sharp decrease in the productivity of hunting activities in the study area can severely affect the food security of the residents and their family incomes. This drastic 
decrease has already been felt by hunters, who have reported increasing difficulties in capturing yellow-footed tortoises. The high value of CPUE found in 2009 resulted from an atypical event of severe drought during that year. The low number of remaining wetlands likely sheltered a large number of tortoises requiring thermoregulation, which attracted hunters to these areas and increased hunting productivity. This event indicates that climate changes in the Amazon could vastly impact the sustainability of tortoise use by Amazonian communities.

Thus, as the productivities of hunting activities decrease, hunters must exert greater effort and incur higher costs to catch tortoises in the wild, elevating the price at the time of sale. Therefore, fluctuations in the price of game showed the same pattern found in the productivity of hunting and were an efficient indicator of unsustainability. van Vliet et al. (2012) reviewed the use of hunting prices as sustainability indicators and criticized this approach because the urban market is supplied from many sources of game meat; thus, trends may not be easily identified. However, our monitoring is based on many sampling years, and we directly monitored the sales price from hunters, the first link in the production chain. In this case, hunting is the main variable that influences tortoise prices.

Converse et al. (2005) suggested that tortoises have low population growth rates, which hinders the recruitment of individuals in the case of mortality on a large scale. In contrast, Hailey (2000) suggested that the spur-thighed tortoise (Testudo graeca) has high productivity under management, indicating potential for its sustainable use. Currently, chelonian conservation projects in the Amazon have focused their efforts more on species that nest on beaches by promoting community-based protection of nesting areas (e.g., Caputo et al. 2005 for Podocnemis unifilis). In contrast, despite being subjected to frequent traditional uses by rural populations, terrestrial chelonian species, such as the yellowfooted tortoise, are rarely included in conservation programs.

\section{Alternatives to mitigate the impacts of yellow-footed tortoise hunting}

Resolving the worldwide bushmeat crisis is difficult because it involves many social, biological, and environmental challenges, which are often particular to each game species. Discussions regarding the best strategies for reducing or mitigating the impacts of hunting are longstanding. Some studies have addressed discouraging the consumption and trade of game by proposing surveillance measures in urban markets, imposing fines and prison sentences for wildlife traders and improving meat price controls, reducing the market price of farm-raised meat, and increasing bushmeat prices (Wilkie and Carpenter 1999, MilnerGulland 2001).

Other authors have proposed maintaining sustainable consumption. One potential measure for achieving consumption sustainability is the implementation of a quota system based on biological information on the species, such as density and reproductive rates, to define a viable number of individuals that could be harvested in the wild. This strategy has been successful in the Amazon for other animal groups (e.g., Arantes et al. 2006) but requires in-depth studies on the reproduction of the target species. Another well-established strategy is the use of zoning areas, which are generally based on the source-sink ecological concept (Wilkie and Carpenter 1999).
In addition to the strategies noted above, the most widely fostered conservation measure is to replace sources of protein and income of rural and urban dwellers by raising and consuming domestic animals (Wilkie and Carpenter 1999). In South American rainforests, domestic animals are always exotic species, and the establishment of livestock-rearing programs is generally accompanied by various environmental impacts. Indeed, raising livestock for consumption in Brazil and in some other parts of the world is one of the most threatening activities to biodiversity because of the massive conversion of forests into pasture (Nasi et al. 2011).

Breeding wild animals in captivity is emerging as a more sustainable animal-rearing alternative (Nogueira and NogueiraFilho 2011). When wild animals are bred, individuals would be biologically adapted to the environmental conditions of the breeding site. Furthermore, this measure maintains the local cultural use of the target species. Laws in Brazil allow for the commercial use of wild animals bred in captivity (Nogueira and Nogueira-Filho 2011). In contrast, hunting wild animals is prohibited, except in situations of extreme need (Law 5,197/67 and Law 9,605/98). However, these prohibitions do not inhibit the consumption and trade of wildlife because surveillance is not effective. The prohibition of hunting or its replacement by domestic meat sources can promote the loss of culture, traditional knowledge, and dietary diversity among rural populations, especially regarding the food sovereignty of traditional communities (Ibarra et al. 2011).

The social, environmental, and biological drivers of the hunting and trade of the yellow-footed tortoise in the Brazilian Central Amazon have been widely elucidated in this study, which has allowed us to suggest appropriate conservation strategies. Strategies aimed at sustainable tortoise harvesting, such as implementing harvest quotas and regulating hunting during reproductive seasons, are more appropriate in upland forest communities that hunt for subsistence and are compatible with the maintenance of the local culture. However, to effectively implement this measure, additional biological information on the reproduction habits of the species is necessary. In contrast, the development of alternative sources of income could be useful for the community users of whitewater flooded forests to decrease their dependence on tortoise hunting. For the urban market, the sustainable rate of yellow-footed tortoise trade must be estimated based on further research on the reproduction habits and resilience of the species, which would enable the market to offer only species within a sufficient consumption rate tolerance, as suggested by Nasi et al. (2011) for Central Africa. Although these strategies are very compatible with local needs, Brazilian laws must be changed to create hunting management rules for consuming and selling species because both activities are currently prohibited for Amazonian wildlife species.

\section{CONCLUSION}

Hunting yellow-footed tortoises plays an important role in the livelihood and income of rural people in the Amazon. However, hunting overexploitation threatens the nutritional quality of the locals' diet as well as their income security. To develop strategies to resolve this situation, the social, biological, and environmental drivers of tortoise hunting must be considered. Policies must consider that different Amazonian environments provide distinct 
patterns of seasonal hunting and animal use, especially regarding the decision to consume or trade tortoises. In addition, rules must be consistent with the biological characteristics of the target species that are preferred by hunters and consumers so that those involved in this hunting system can more easily comply with regulations. It is impossible to unlink rural community activities and the urban market when implementing policies aimed at resolving the worldwide bushmeat crisis. Thus, a combination of mitigation measures that consider both population segments can contribute to sustainable hunting maintenance in the Amazon in a manner that is compatible with the conservation of biodiversity, the permanence of local cultures, and food security assurance.

Responses to this article can be read online at: http://www.ecologyandsociety.org/issues/responses. $\mathrm{php} / 7701$

\section{Acknowledgments:}

We thank the National Council for Scientific and Technological Development (Conselho Nacional de Pesquisa e Inovação; $C N P q$ ) and the Ministry of Science, Technology and Innovation (Ministério da Ciência, Tecnologia e Inovação; MCTI) for their financial support. We also thank H. R. El Bizri for his support in revising the text, E. O. Neves and C. Franco (GIS/IDSM) for producing the map, and the community members of the two reserves who gently provided us with valuable information.

\section{LITERATURE CITED}

Aiyeloja, A. A., and O. I. Ajewole. 2006. Non-timber forest products' marketing in Nigeria. A case study of Osun state. Educational Research and Reviews 1(2):52-58.

Albrechtsen L., D. W. Macdonald, P. J. Johnson, R. Castelo, and J. E. Fa. 2007. Faunal loss from bushmeat hunting: empirical evidence and policy implications in Bioko Island. Environmental Science \& Policy 10:654-667. http://dx.doi.org/10.1016/j. envsci.2007.04.007

Aquino, R., T. Pacheco, and M. Vásquez. 2007. Evaluación y valorización económica de la fauna silvestre en el río Algodón, Amazonía peruana. Revista Peruana de Biologia 14(2):187-192. http://dx.doi.org/10.15381/rpb.v14i2.1730

Arantes, C. C., L. Castello, and D. Garcez. 2007. Densidades de pirarucu (Arapaima gigas, Teleostei, Osteoglossidae) em lagos das reservas de Desenvolvimento Sustentável Mamirauá e Amanã, Amazonas, Brasil. Uakari 2:37-43.

Ayres, J. M., D. M. Lima, E. S. Martins, and J. L. K. Barreiros. 1991. On the track of the road: changes in subsistence hunting in a Brazilian village. Pages 82-92 in J. G. Robinson and K. H. Redford, editors. Neotropical wildlife use and conservation. University of Chicago Press, Chicago, Illinois, USA.

Bennett, E. L., E. Blencowe, K. Brandon, D. Brown, R. W. Burn, G. Cowlishaw, G. Davies, H. Dublin, J. E. Fa, E. J. MilnerGulland, J. G. Robinson, J. M. Rowcliffe, F. M. Under-Wood, and D. S. Wilkie. 2007. Hunting for consensus: a statement on reconciling bushmeat harvest, conservation and development policy in west and central Africa. Conservation Biology 21:884-887. http://dx.doi.org/10.1111/j.1523-1739.2006.00595.x

Bisbal, F. 1994. Consumo de fauna silvestre en la zona de Imataca, estado Bolívar, Venezuela. Interciência 19(1):1-6.

Bodmer, R. E., and E. P. Lozano. 2001. Rural development and sustainable wildlife use in Peru. Conservation Biology 15:1163-1170. http://dx.doi.org/10.1046/j.1523-1739.2001.0150041163. $\underline{x}$

Caputo, F. P., D. Canestrelli, and L. Boitani. 2005. Conserving the terecay (Podocnemis unifilis, Testudines: Pelomedusidae) through a community-based sustainable harvest of its eggs. Biological Conservation 126(1):84-92. http://dx.doi.org/10.1016/j. biocon.2005.05.004

Colinvaux, P. A., and M. B. Bush. 1991. The rain-forest ecosystem as a resource for hunting and gathering. American Anthropologist 93:153-160. http://dx.doi.org/10.1525/aa.1991.93.1.02a00100

Converse, S. J., J. B. Iverson, and J. A. Savidge. 2005. Demographics of an ornate box turtle population experiencing minimal human-induced disturbances. Ecological Applications 15 (6):2171-2179. http://dx.doi.org/10.1890/04-0431

de Queiroz, H. L. 2011. Protected areas in the Amazonian Várzea and their role in its conservation: the case of Mamirauá Sustainable Development Reserve (MSDR). Pages 465-483 in W. J. Junk, M. T. F. Piedade, F. Wittmann, J. Schöngart, and P. Parolin, editors. Amazonian floodplain forests. Springer, Dordrecht, The Netherlands. http://dx.doi.org/10.1007/978-90-481-8725-6 22

De Souza-Mazurek, R. R., T. Pedrinho, X. Feliciano, W. Hilário, S. Gerôncio, and E. Marcelo. 2000. Subsistence hunting among the Waimiri Atroari Indians in central Amazonia, Brazil. Biodiversity and Conservation 9:579-596. http://dx.doi.org/10.1023/ A:1008999201747

Fa, J. E., L. Albrechtsen, P. J. Johnson, and D. W. Macdonald. 2009. Linkages between household wealth, bushmeat and other animal protein consumption are not invariant: evidence from Rio Muni, Equatorial Guinea. Animal Conservation 12:599-610. http://dx.doi.org/10.1111/j.1469-1795.2009.00289.x

Fa, J. E., and C. A. Peres. 2001. Game vertebrate extraction in African and Neotropical forests: an intercontinental comparison. Pages 203-241 in J. D. Reynolds, G. M. Mace, J. G. Robinson, and K. H. Redford, editors. Conservation of exploited species. Cambridge University Press, Cambridge, UK.

Fachin-Terán, A., R. C. Vogt, and J. B. Thorbjamarson. 2004. Patterns of use and hunting of turtles in the Mamirauá Sustainable Development Reserve, Amazonas, Brazil. Pages 362-377 in K. M. Silvius, R. E. Bodmer, and J. M. V. Fragoso, editors. People in nature: wildlife conservation in South and Central America. Columbia University Press, New York, New York, USA.

Ferreira-Ferreira, J., T. S. F. Silva, A. S. Streher, A. G. Affonso, L. F. A. Furtado, B. R. Forsberg, J. Valsecchi, H. L. Queiroz, and E. M. L. M. Novo. 2015. Combining ALOS/PALSAR derived vegetation structure and inundation patterns to characterize major vegetation types in the Mamirauá Sustainable 
Development Reserve, Central Amazon floodplain, Brazil. Wetlands Ecology and Management 23:41-59. http://dx.doi. org/10.1007/s11273-014-9359-1

Hailey, A. 2000. Implications of high intrinsic growth rate of a tortoise population for conservation. Animal Conservation 3:185-189. http://dx.doi.org/10.1111/j.1469-1795.2000.tb00102. $\underline{x}$

Hurtado-Gonzales, J. L., and R. E. Bodmer. 2004. Assessing the sustainability of brocket deer hunting in the TamshiyacuTahuayo Communal Reserve, northeastern Peru. Biological Conservation 116:1-7. http://dx.doi.org/10.1016/S0006-3207(03) $\underline{00167-8}$

Ibarra, J. T., A. Barreau, C. Del Campo, C. I. Camacho, G. J. Martin, and S. R. Mccandless. 2011. When formal and marketbased conservation mechanisms disrupt food sovereignty: impacts of community conservation and payments for environmental services on an indigenous community of Oaxaca, Mexico. International Forestry Review 13(3):318-337. http://dx. doi.org/10.1505/146554811798293935

International Union for Conservation of Nature and Natural Resources (IUCN). 2013. IUCN red list of threatened species. Version 2013.1. IUCN, Cambridge, UK. [online] URL: http:// www.iucnredlist.org

Jerozolimski, A. 2005. Ecologia de populações dos jabutis Geochelone denticulata e G. carbonaria (Cryptodira: Testudinidae) no território da aldeia A'Ukre, Terra Indígena Kaiapó, sul do Pará. Thesis. Universidade de São Paulo, São Paulo, Brazil.

Koster, J. M. 2008. Hunting with dogs in Nicaragua: an optimal foraging approach. Current Anthropology 49(5):935-944. http:// dx.doi.org/10.1086/592021

Milner-Gulland, E. J. 2001. Assessing sustainability of hunting: insights from bioeconomic modelling. Pages 113-151. in M. I. Bakarr, G. A. B. Fonseca, R. A. Mittermeier, A. B. Rylands, and K. W. Painemilla, editors. Hunting and bushmeat utilisation in the African rainforests: perspectives towards a blueprint for conservation action. Conservation International, Washington, D. C., USA.

Nasi, R., A. Taber, and N. van Vliet. 2011. Empty forests, empty stomachs? Bushmeat and livelihoods in the Congo and Amazon Basins. International Forestry Review 13(3):355-368. http://dx.doi. org/10.1505/146554811798293872

Nielsen M. R., and H. Meilby. 2015. Hunting and trading bushmeat in the Kilombero Valley, Tanzania: motivations, costbenefit ratios and meat prices. Environmental Conservation 42 (1):61-72. http://dx.doi.org/10.1017/s0376892914000198

Nogueira, S. S. C., and S. L. G Nogueira-Filho. 2011. Wildlife farming: an alternative to unsustainable hunting and deforestation in Neotropical forests? Biodiversity and Conservation 20:1385-1397. http://dx.doi.org/10.1007/s10531-011-0047-7

Páez, V. P., M. A. Morales-Betancourt, C. A. Lasso, O. V. Castaño-Mora, and B. C. Bock, editors. 2012. Biología y conservación de las Tortugas Continentales de Colombia. Serie Editorial Recursos, Hidrobiológicos y Pesqueros Continentales de Colombia. Instituto de Investigación de Recursos Biológicos Alexander von Humboldt, Bogotá, Colômbia.

Peres, C. A. 1999. Nonvolant mammal community structure in different Amazonian forest types. Pages 564-581 in J. F. Eisenberg and K. H. Redford, editors. Mammals of the Neotropics: the central Neotropics. University of Chicago Press, Chicago, Illinois, USA.

Peres, C. A. 2000. Effects of subsistence hunting on vertebrate community structure in Amazonian forests. Conservation Biology 14(1):240-253. http://dx.doi.org/10.1046/j.1523-1739.2000.98485. $\underline{\mathrm{X}}$

Redford, K. H. 1997. A floresta vazia. Pages 1-22 in C. ValladaresPadua, R. E. Bodmer, and L. Cullen, Jr., editors. Manejo e conservação de vida silvestre no Brasil. MCT-Cnpq/Sociedade Civil Mamirauá, Brasília, Distrito Federal, Brazil.

Ross, E. B., M. L. Arnott, E. B. Basso, S. Beckerman, R. L. Carneiro, R. G. Forbis, K. R. Good, K. Jensen, A. Johnson, J. Kaplinski, R. S. Khare, O. F. Linhares, P. S. Martin, B. Nietschmann, G. T. Nurse, N. J. Pollock, I. Sahai, K. C. Taylor, D. Turton, W. T. Vickers, and W. E. Wetterstrom. 1978. Food taboos, diet, and hunting strategy: the adaptation to animals in Amazon cultural ecology. Current Anthropology 19:1-36.

Rushton, J., R. Viscarra, C. Viscarra, F. Basset, R. Baptista, and D. Brown. 2005. How important is bushmeat consumption in South America: now and in the future? ODI Wildlife Policy Briefing Number 11. Overseas Development Institute, London, UK.

Turtle Conservation Coalition [A .G. J. Rhodin, A. D. Walde, B. D. Horne, P. P. Van Dijk, T. Blanck, and R. Hudson, editors]. 2011. Turtles in trouble: the world's $25+$ most endangered tortoises and freshwater turtles-2011. IUCN/SSC Tortoise and Freshwater Turtle Specialist Group, Turtle Conservation Fund, Turtle Survival Alliance, Turtle Conservancy, Chelonian Research Foundation, Conservation International, Wildlife Conservation Society, and San Diego Zoo Global, Lunenburg, Massachusetts, USA.

Valsecchi, J., and P. V. Amaral. 2009. Perfil da caça e dos caçadores na Reserva de Desenvolvimento Sustentável Amanã, Amazônas —Brasil. Uakari 5(2):33-48.

Valsecchi, J., H. R. El Bizri, and J. E. C. Figueira. 2014. Subsistence hunting of Cuniculus paca in the middle of the Solimões River, Amazonas, Brazil. Brazilian Journal of Biology 74(3):560-568. http://dx.doi.org/10.1590/bjb.2014.0098

van Vliet, N., and P. Mbazza. 2011. Recognizing the multiple reasons for bushmeat consumption in urban areas: a necessary step toward the sustainable use of wildlife for food in Central Africa. Human Dimensions of Wildlife 16:45-54. http://dx.doi. org/10.1080/10871209.2010.523924

van Vliet, N., O. Mertz, A. Heinimann, T. Langanke, U. Pascual, B. Schmook, C. Adams, D. Schmidt-Vogt, P. Messerli, S. Leisz, J.-C. Castella, L. Jörgensen, T. Birch-Thomsen, C. Hett, T. BechBruun, A. Ickowitz, K. C. Vu, K. Yasuyuki, J. Fox, C. Padoch, W. Dressler, and A. D. Ziegler. 2012. Trends, drivers and impacts of changes in swidden cultivation in tropical forest-agriculture frontiers: a global assessment. Global Environmental Change 22 (2):418-429. http://dx.doi.org/10.1016/j.gloenvcha.2011.10.009 
van Vliet, N., and R. Nasi. 2008. Hunting for livelihood in northeast Gabon: patterns, evolution, and sustainability. Ecology and Society 13(2): 33. [online] URL: http://www.ecologyandsociety. org/vol13/iss2/art33/

van Vliet, N., M. P. Quiceno-Mesa, D. Cruz-Antia, L. J. N. Aquino, J. Moreno, and R. Nasi. 2014. The uncovered volumes of bushmeat commercialized in the Amazonian trifrontier between Colombia, Peru \& Brazil. Ethnobiology and Conservation $3: 1-7$.

Wilkie, D. S., and J. F. Carpenter. 1999. Bushmeat hunting in the Congo Basin: an assessment of impacts and options for mitigation. Biodiversity \& Conservation 8:927-955. http://dx.doi. org/10.1023/A:1008877309871 